Прегледни рад

Владимир Јерковић

Сомбор

vladimirjerkovic@yahoo.com
UDK 070(=163.42)(497.113)"1882/1944"

https://doi.org/10.18485/

bibliotekar.2018.60.2.9

\title{
ПЕРИОДИКА НА БУЊЕВАЧКОМ ЈЕЗИКУ У СОМБОРУ 1882-1944
}

\begin{abstract}
Сажетак: Овај рад представља покушај сажетог систематичног приказа штампе на буњевачком језику која је или излазила у Сомбору или је одређени период, као што је то случај са листом Невен, Сомбор био место излажења. Рад представља варијанту објективног документовања, један покушај осврта, сачињен, како од сегмената садржаја сваког од приказаних листова, тако и сижеа, карактеристичних одредница, које се односе на пет листова који су важан сегмент буњевачке грађанске културне баштине. Једна специфична, недовољно актуелизована књижевна појава штампе на буњевачком језику овде јесте централна тема која омогућава непосредан увид и у изабране аутентичне пасусе новина које су историјско сведочанство активности буњевачког грађанског слоја у циљу очувања свог националног идентитета на територији Града Сомбора, или још шире, на подручју Бачке. У Сомбору је излазило пет листова у периоду 1882-1944: Буюеваи: листи обће наобразбе и найрияка, Невен: забавни и йоучни мисечник, војвоgина:

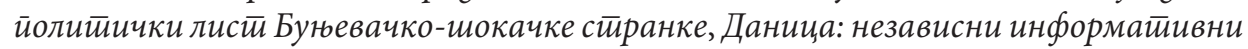

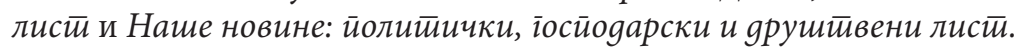

Кључне речи: периодика, буњевачки језик, Сомбор, Буњевци, књижевност, политика.

\section{Увод}

Након стицања Повеље елибертације ${ }^{1} 1749$. године развој Сомбора, као града, постаје убрзан, планиран и град постепено израста у све већи центар све ширег подручја, односно с временом постаје и административно, образовно, културно и верско средиште бачких Срба и Буњеваца. С

Више о томе видети у: Милош Петровић и Владимир Јерковић, Алтиернатиива-Повель-

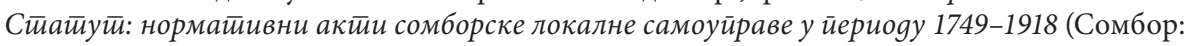
Градска библиотека „Карло Бијелицки”, 2016). 
временом, мада веома рапидно, Сомбор израста у значајан трговачки центар, отварају се прве школе и здравствене установе и долази до повећања броја становника. Године 1802. град и формално постаје седиште Бачкободрошке жупаније и преузима функцију административног и културног центра овог дела Хабзбуршке монархије. Стварају се услови за културну и образовну делатност.

Године 1850. Карло Битерман (Bittermann) отвара прву штампарију и утире пут развоју штампарства у Сомбору. Петнаест година касније, 1865 , појављује се и прва штампана периодика. У време појаве првог листа у Сомбору овај део Бачке припадао је Хабзбуршкој монархији која је, ускоро, 1867. године трансформисана у двојну, Аустроугарску монархију. Војводина (јужна Угарска) потпада под директну управу Угарске, а слободни краљевски градови, какав је био и Сомбор, имали су аутономију. Ипак, општи развој културно-просветног живота половином XIX века био је условљен политиком Аустроугарске. У вишенационалној средини, у време испољавања национализма и развоја грађанских националних политичких партија, сваки народ је настојао да има штампу на свом језику, што у датим историјским околностима није увек био лак задатак. ${ }^{2}$

Периодика у Сомбору објављивана је на српском, мађарском, немачком и буњевачком језику. Штампа је била разноврсна, од политичко-информативних листова, гласила политичких странака до специјализоване штампе са историјским, економским, пољопривредним, верским и књижевним садржајем.

У зборнику радова Истиорија Сомбора - ірраg кроз векове, који су приредили др Милош Петровић и др Владимир Јерковић, др Каталин Каић појашањава базу, стварање услова за настанак и јачање штампе у грађанском Сомбору друге половине деветнаестог века. Професорица Каић пише да је привредна експанзија после 1867. године подстакла културне захтеве варошана, пружила почетне замахе, те активирала нарасле интелектуалне потенцијале. Као резултат тога, осамдесетих година деветнаестог века основано је неколико културних институција којима је Сомбор успео да пробије баријере провинцијализма, истакла је др Каић. „Снажнији кораци у културном животу чињени су, углавном, упоредо са савременим тенденцијама, мада су некад потези вучени и са закашњењем, али су и закаснеле

Више о томе видети у: Наташа Плавшић и Горана Копоран, 150 їодина сомборске йериоgике, каталог изложбе (Сомбор: Градска библиотека „Карло Бијелицки”, 2016). 
иницијативе, гледано из ове временске перспективе, дале допринос стварању културног миљеа града."

Из свега до сада наведеног, свакако у кратким цртама, произлази један специфични миље сомборски, при којем се појављују и смењују различите новине, листови и часописи, међу којима се издвајају и листови на буњевачком језику, који се налазе у фонду периодике у Градској библиотеци „Карло Бијелицки” у Сомбору, у фонду Библиотеке Матице српске и Народне библиотеке Србије. Учинити доступним библиотечку грађу, у овом случају периодична издања, представља важан задатак сваке средине, уколико озбиљно сагледава сопствену прошлост и жели црпити конкретне изворе. Наиме, уз виталне институционалне партнере и уз подршку оснивача Града Сомбора, сомборској библиотеци дато је централно место, по међународним пројектним стандардима, за прикупљање великог броја дигитализованих објеката и изградњу дигиталних збирки. Одабрану грађу библиотека представља у оквиру портала Дигитална библиотека Србије, кроз пројекат Дигитални Сомбор и партнерске дигиталне пројекте. У припреми, дигитализацији и архивирању грађе, уз библиотекаре учествују бројни стручни сарадници ангажовани по програмима и разноврсним пројектима, док је евидентан и мерљив број дигитализованих јединица, унесених метаподатака, као и урађених библиографија периодике. Имајући у виду континуираност пројекта Дигитални Сомбор сведоци смо рада и обраде периодичних издања која су излазила у Сомбору, од чега је велики број постављен на сервер библиотеке и онлајн је доступан свим корисницима, без надоканде или ограничења. У саставу стално развијајуће и

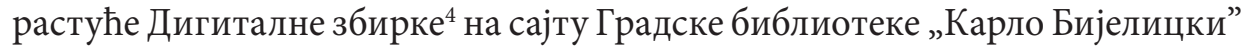
у Сомбору налазе се, када говоримо о штампи на буњевачком језику, сви дигитализовани бројеви листа Наше новине, о којем ће читалац, између осталог, бити у прилици да сазна у тексту који следи.

Свако прелиставање периодике поучи читаоца, пружи одређена сазнања, али и изнова потврђује улогу коју је Град Сомбор имао у XIX веку, а када је реч о периодици на српском језику, али и на језицима других народа, која је читана надалеко, а представљала је пионирске подухвате великих ентузијаста и племенитих раванградских појединаца који су овај град учинили великим и значајним, превасходно за српски народ. И заиста, Сомбор у једном периоду представља не само центар образовања за учитеље на

\footnotetext{
Више о томе видети у: Милош Петровић и Владимир Јерковић, Исӣорија Сомбора - іраg кроз векове (Сомбор: Градска библиотека „Карло Бијелцики”, 2018), 440.

4 Дигитална збирка је доступна на http://www.biblioso.org.rs/digitalna_zbirka.php?lng=ci.
} 
српском језику, него и центар културе и средину из које израстају многи од великана српских, заслужних за установљење првих модерних националних институција, које су се низале у Кнежевини, а потом и Краљевини Србији. Тај контакт, тај рад и то прегалаштво, не само да је видљиво кроз залагање Сомбораца ${ }^{5}$ у бројним задацима оснивања најважнијих установа попут Матице српске, Друштва српске словесности, високих школа/ факултета, министарстава итд., него је још упадљивији управо штампани медиј, који сведочи о доприносима Сомбораца, медиј путем којег су издавачи досезали до читалаца у свим крајевима Балкана насељених Србима. У тим и таквим околностима, вековно везан за Србе, буњевачки народ је у слози са српским на овим поднебљима упоредо заживео и опстојавао све до пред крај Другог светског рата, када је једном декларацијом ${ }^{6}$ укинуто право, односно могућност самоодређења и изјашњавања према националности Буњеваца и Шокаца, као засебног и својственог народа са правом самоопредељења, односно када је кроатизација ових народа и системски била настављена, овога пута од стране политичких актера тога времена, а у новононасталој Федеративној Народној Републици Југославији. ${ }^{7}$ Па, ипак, сведоци смо да су обичаји, култура и језик сачувани, те да смо сада управо у времену пролиферације, можда боље речено поновне актуелизације буњевачке националности и то најинтензивније, готово искључиво, у оквирима Републике Србије, ако поредимо са државама околним, у региону, у којима је овај народ, такође, вековима настањен.

Разноврсност сомборске периодике, живуће и трајуће већ век и по, указује на значај града као центра из којег је ширена писменост, за Србе веома је важно да је чувано ћирилично писмо, али и негован буњевачки језик, вршено образовање и информисање читалаца на толико различитих начина и толико разнородних тематских области, међу којима издвајамо пет листова на буњевачком језику, који су излазили у Сомбору као штампана издања. Треба навести и то да овај рад јесте скраћена и преправљена још необјављена књига која садржи и фототипске прилоге и прегрш чланака а замишљена је као спомен-издање листова који су излазили у Сомбору а

\footnotetext{
Више о томе видети у: Стеван Васиљевић, Знаменитии Сомборизи (Нови Сад: Славија, 1989).

6 Реч је о декларацији Главног народноослободилачког одбора Војводине, одељења за унутрашње послове, број 1040/1945 од 14. 5. 1945. г. донете у Новом Саду у којој је, између осталог, наређено издавање нових легитимација за Буњевце и Шокце у којима се у одељку за националност употребљава реч хрвайска.

7 Више о томе видети: https://www.subotica.com/vesti/bunjevacki-savet-trazi-donosenjedeklaracije-o-ponistavanju-akta-nasilne-asimilacije-bunjevaca-id31962.html.
} 
намењени су Буњевцима и Шкоцима. Циљ сачињавања оваквог рада јесте покушај сакривања од заборава и овог дела завичајне прошлости нарочито важне за буњевачки живаљ настањен у Аустроугарској монархији, потом у Краљевини Југославији, у оквирима којих држава је Буњевачко-шокачка популација водила једну врло артикулисану, непрекидну и неуморну борбу за очување језика, културе, писма и националног идентитета. У тој борби, тим стремљењима очувања дуга према прецима, незаобилазну улогу имала је штампа, попут листова који су сабрани у овом издању, у којима су на свом матерњем језику Буњевци могли бити информисани, учити и сазнавати о много чему, али опет нечему толико карактеристичном за војвођанско поднебље, у разноврсним чланцима и календарима ${ }^{8}$ који су дефинитивно били заступљени у пет различитих и разновремених штампаних периодичних издања за која имамо сазнања и материјалне доказе да су излазила у Сомбору у периоду 1882-1944. г.

\section{О периодици на буњевачком језику објављиваној у Сомбору}

У току маја месеца 2018. године у организацији Регионалне канцеларије Националног савета буњевачке националне мањине у Сомбору и Центра за културу Буњеваца из Суботице, у свечаној жупанијској сали одржана је јединствена трибина под називом „Три и по вика буњевачке писмености у Сомбору и Бачкој”. О најстаријим траговима писмености сомборских и бачких Буњеваца, од рукописа и првих штампаних књига, до буњевачке периодике, излагали су Милан Степановић, публициста и завичајни историчар, Невенка Башић Палковић, библиотекар саветник и кустос из Суботице и др Владимир Јерковић, филолог. Овим предавањем је обележена 350-та годишњица од најстаријих трагова буњевачке писмености у сомборској вароши, али и на целом простору Бачке, и 150-та годишњица од зачетка буњевачке периодике. Прва два говорника, веома подробно и исцрпно упознати са тематиком, покушали су да одреде који су то први писани документи на говору буњевачком и када се појављују. О писаној речи на језику Буњеваца, на просторима данашње Војводине, нешто више о записима на буњевачком језику, могло се чути од уважених

8 Више о календарима на буњевачком језику уопште, видети у радовима Невенке Башић Палковић, док конкретно, везано за Сомбор, видети у Буњевачким новинама у броју 154 из априла 2018. г. на странама 24-25 на којима Милан Степановић пише о улози сомборског буњевачко-шокачког календара за 1882. г. у буђењу националне свести. 
говорника а више пута се прича о сомборској штампи намењеној буњевачкој популацији враћала почецима исте, која је опет, понајвише била заступљена у Суботици, као својеврсном центру бачких Буњеваца. Објављивање првога броја Буюевачких и шокачких новина 1870, које је покренуо бискуп Иван Антуновић, представља зачетак штампе на икавици у Јужним крајевима, како су Мађари називали ове просторе. Па ипак, важно је истаћи да је поменути лист излазио у Калочи, данас у Републици Мађарској, дакле месту у којем је излазила и Буюевачка вила, од 1873. као самостална новина под уредништвом Блажа Модрошића. С обзиром на то да је овде у фокусу историја Града Сомбора, овај рад представља остварење намере сведочанства о периодици, дакле штампи, која је излазила у Сомбору, а на буњевачком језику, у обиму довољноме и примереноме да читалац буде упознат са тематиком, све у складу са оним што смо истражили, односно били у могућности да то учинимо, срећом, при очуваним и евидентираним доступним изворима.

Оно најуопштеније што се може рећи јесте да су на буњевачком језику штампана гласила махом политичке садржине, мећутим, значајна су због других, разнородних прилога и понајпре су значајна јер су писана према матерњем говору Буњеваца, те стога представљају сведочанство о једној специфичној националној култури. Наиме, управо штампана периодика и јесте један део културне баштине Буњеваца и представља, свакако, један од темеља националног идентитета овога народа.

Важно је напоменути да је приређивач имао непосредан увид у примарне изворе, те да је из тих и таквих материјала за изучавање, односно сачуваних примерака листова, али и дигитализованог садржаја, сачинио овај језгровити преглед историјата и садржаја штампе о којој је реч.

\section{Буњевач: листи обће наобразбе и найрияка}

Испрва се појавио општеобразовни недељник под називом Буюеваи: листи обће наобрзбе и найрияка 1882. год., док је година престанка излажења непозната, барем према нашим сазнањима али и према списима г. Радивоја Стоканова који је провео читав радни век при завичајном одељењу сомборске библиотеке. Излазио је пред читаоце сваког петка а доносио је обраћање уредника, дописе, осврте и књижевне прилоге редовно, затим путописе, корисне савете из виноградарства, пчеларства, пољипривреде. Веома упечатљиво је, да су се на страницама овог недељника могле пронаћи веома често препоруке за образовање и васпитање младих. Овде 
издвајамо део чланка из трећег броја, са прве стране, из наставка рубрике O оріоливану:

„...Шта вам вриди сад, што вам је ђак научио природопис, словницу, догодовштину итд., кад није научио законе кршћанске, у којима би - међу другим - и то научио био: Поштуј отца и матер!

Научио вам џак по свитовним обичају: да новац, богатство управља свит (Geld regiert die Welt) заото у родитељима воли богатство, и извано их штује, док му добро своје не припишу - а осим тога су родитељи досадни."

Дакле, лист Буњевац личи донекле, узето према одређеним садржајним сегментима на Домаћи листи, који је такође излазио у Сомбору, и доносио је сличне прилоге, али нешто кохерентније него недељник Буневац. Наиме, лист је декларативно био усмерен ка општем образовању, обавештавању и напретку, како је наведено. Уредник је био Иван Батори, штампан је код Фердинанда Битермана у Сомбору, формат листа је био 28 ca 39,3 цм, на 4 стране, и мада није познато када је престао са излажењем, претпостављамо да није излазио ни пуну годину, иако може бити случај да негде при другим фондовима ван сомборског одељења периодике има других бројева, што је мало вероватно. Као сарадник, при дну завршног ступца свакога броја, наведен је Иван Палић. У овом гласилу могли су бити прочитани спомени за преминуле знамените особе, али, назовимо то, и лирским некролозима попут оних стихова, међу којима можемо издвојити

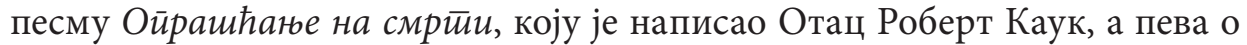
суочавању са смрћу. Међутим, за потребе овога рада ипак неће бити места и за саме цитате и одломке.

Редовне рубрике у листу Буюеваи носиле су називе: Сйаровина, Изја-

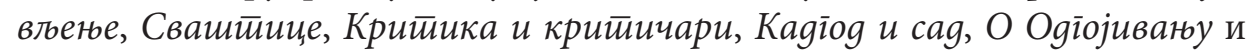
то су оне рубрике за које је јасно да су биле присутне у свим доступним бројевима. Без обзира што овај лист није потрајао, остао је забележен као најстарије штампано гласило Буњеваца које је излазило у Сомбору.

\section{Невен: забавни и иооучни мисечник}

Наредни лист је лист дугога века трајања, Невен: буюевачко-шокачки $\pi u c \bar{u}$, који је излазио у једном периоду и у Сомбору, пре тога у Баји, а после сомборског периода у Суботици. Од 1884. испрва је под уредништвом Мије Мандића, да би се у току дугог низа година мењали уредници. Лист, под тим називом, излазио је, уз прекиде, све до 1940. године. Неко време Невен: буюевачко-шокачки листи био је дневни лист, али био је и месечник, 
политичке оријентације су варирале, садржај и рубрике се мењале као и сам изглед новина. У време излажења у Сомбору штампан је у Брзотиску Мужика и Партлића у Сомбору, и то за прво годиште на 192 стране, али тек од бр. 7-12, затим у другом годишту 1885. године од 6р. 1-12. Наредно, треће годиште, такође је у потпуности штампано у Сомбору у истој штампарији, да би пре пресељења за Суботицу у четвртој години, према томе већ 1887, у Сомбору били одштампани бројеви 1-5.

Занимљиви тесктови су нашли места у Невену. Овде издвајамо одломак прилога Шӣо̄og о ракијu, који је написао фратар чији су иницијали били С. М.-ћ, и који започиње краћим стихом:

„Hије gобро йит̄ ракију

Og тье тьуди рано мрију

Литии сущи, зими гуши

Паметиан се ғом неслужи.

Крунослав.

У предзадњем броју нашег мезимчетиа спомену штовани писац С-у свом Шокачком иичсму Невена онај отров, који већ по више столића грозовито тресе нашим народом, а тај се, без двојбе, отровна капљица, или правим именом ракија називље. - Да већма подкрипим основу г. писца С..., а и властитој жељи задовољим, одлучио сам губимцем ракије свеобће одкрити мане тога пића и тиме, по могућности доказати, да ракија трује живот, и приправља човику рану смрт. У ту сврху подлогом ми служи књижица, нимачкога писца, Албана Штолца, кој нас обће позивља, да чешће држимо лов на йијанце."

И мада дуговечан и значајан, те повезан и уврштен и у сомборску периодику, лист је излазио најдужи период у Суботици. У првом броју који је изашао у Сомбору уредник Мијо Мандић у броју 7, на насловној страни текстом Друі̄o йолуїодишие обраћа се читаоцима речима:

„Овим бројем настаје друго полугодиште нашег мезимчета Невена.

Околности су нам се тако проминуле, да се је Невен из Баје, под пријазније поднебље - у Зомбор примистити морао. Хвала Богу на милости, да смо и ову промину без икакве веће неприлике учинити могли. А ово само користити може Невену.

Пол године је истом ево, одкада смо - из родо, - и домољубне љубави - овај мисичник и покренули. Доста кратак вик, дакако, на пољу књижевном, ал довољан на то: да велику потрибоћу овога мисечника још већма упознамо." 
Невен је био, по скромном мишљену приређивача овог приказа, најцеловитији, најсврсисходнији и најбоље арикулисан, свакако најдуговечнији лист на језику Буњеваца, за који знамо са потпуном сигурношћу да је излазио у Граду Сомбору. Ова тврдња ни у чему не умањује претходећи или долазеће листове о којима пишемо, али стоји као констатација на здраворазумским основама, поткрепљена евидентним чињеницама. Невен је садржавао бројне књижевне прилоге међу којима вреди поменути песму из прве године са 99. стране, коју је потписао П. Р. К. под називом У йољу. ${ }^{9}$

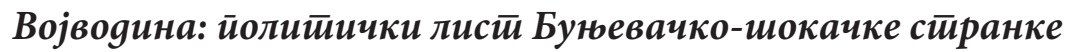

Након Невена уследила је прилична пауза када је реч о сомборској буњевачкој штампи и објављивању. За време Краљевине Југославије 1927. г. излази недељник Bojвоguна, чији је и власник и главни уредник био Ернест Бошњак. Војводина је била политички лист ондашње Буњевачко-шокачке странке.

Приликом посете књижњичара из Националне и свеучилишне књижнице у Загребу 2015. године сомборској библиотеци, посредством колега из Суботице, успели смо обезбедити сва доступна дигитализована издања, дакле дигитализоване бројеве ових новина, које се од тада чувају и при Завичајном одељењу сомборске библиотеке.

У првом броју уредник Ернест Бошњак наводи разлоге покретања новина:

„Под овим насловом, на молбу и захтив наших пријатеља и знанаца покренули смо лист Буњевачке и Шокачке Странке у Сомбору.

Ова Буњевачка и Шокачка Странка је она странка, која хоће да уз помоћ Божју води такву политику, која нас Буњеваца-Шокаца и осталих народности у Војводини може сигурно и без потреса водити у бољу и срићнију будућност.

Она је основана још године 1919. Програм јој је стари: равноправност и слобода у свим гранама државног живота.

Нарочито тражи да су сви држављани прид законом једнаки без вире и народности."

Када говоримо о листу Војвоgина, морамо истаћи да је то лист који садржи текстове пропагандне садржине, али и да се у, рецимо, једној ру-

Када буде објављена књига о буњевачкој периодици у њој ће се наћи и ова песма као и други бројни књижевни прилози. 
брици, названој Којешӣа, јављају кратке приче, писма читалаца, вести разноразне, и оно што можемо разумети као некакву локалну хронику. Па, ипак, пре свега ове новине служиле су информисању о политичким догађајима, изборним радњама, извештајима са скуштинских седница, различитих скупова и конференција, објављиване су тржишне цене производа итд. У Војвоgини се оглашавало, лист је доносио новости из привреде и економије и, наравно, временску прогнозу. Приметно је да су многи од текстова преведени на мађарски језик, односно део сваког броја јесте на мађарском језику. Готово да је лист у потпуности двојезичан од првог до последњег објављеног броја, али морамо приметити да нису сви чланци превођени на мађарски језик. У броју од 14. 8. 1927. на страни 4 налази се песма Војвођанима!, односно политичка парола у рими, написана од стране Јозе Новоселца из Барање. Управо овакав један пример одлично илуструје политичку оријентацију листа.

Памфлети, програми странке, листе кандидата, агитација, вести о активности Хрватске сељачке странке, предизборна кампања јесу одреднице које овај лист чине пропагандним медијем Буњевачко-шокачке странке, а кулминацију свега објављиваног понајвише илуструје парола у каснијим бројевима листа:

„Који љуби војвођанску Аутономију нека гласа у девету кутију.”

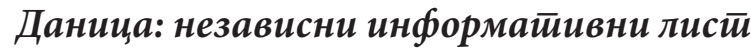

Потом, доласком тридесетих година двадесетог века, а онда и ратних година, мислимо на Други светски рат, штампа у Сомбору не замире, па ни на буњевачком језику, и ту се појављују Наше новине, као својеврсни куриозитет, верујемо садржајем занимљив за проучавање историчарима. (Истоименог наслова тридесет и више година раније излази недељни лист у Суботици, те ова два листа никако не треба мешати.)

Уредник Грго Вуковић, родом из Чонопље, раније је, још као члан ХСС (Хрватске сељачке странке) и Војвођанског покрета, прво писао за Данииу: независни информатиивни листи, а потом од броја 4 и уређивао лист, који је излазио 1934, у време Шестојануарске диктатуре у Сомбору, од 1. фебруара до 31. августа те године. Даница: независни инбормаиивни листи био је у власништву Стипана Дујмовића, излазио је у формату од 46 цм, једном недељно и то четвртком. Како се наводи у самом листу, циљ објављивања је било национално и културно просвећивање Буњеваца и Шокаца. У Народној библиотеци Србије налазе се сви бројеви, у фонду 
периодике, уведени су у систем COBISS и чекају заинтересованог истраживача да их прочита, сачини приказ и евентуално библиографију. Уосталом, свако истраживање периодике јесте плодотоворно, иако веома захтевно, како због теже приступачности изворима, тако и често због делимично сачуваних извора, а овде имамо још један, слабо истражен, материјални доказ постојања штампаног медија на буњевачком језику.

У првом броју на страни 3 Даница доноси списак нових чланова Владе Краљевине Југославије, стубац у којем се наводе подаци у вези са подизањем модерне градске болнице у Сомбору, али и причу Ойклаga, аутора потписаног иницијалима Б. М.ић у рубрици Прича Данице. На првој, насловној, страни првог броја уредништво се обраћа читаоцима наводећи поводе, разлоге и мотиве за покретање листа, као и тенденције ка којима је овај лист оријентисан, а о чему сведочи и наредни одломак:

„Имали смо листова можда и више него што нам је трибало, али су ти листови били већином у служи разних политичких партија, који нису водили рачуна о културним, просвитним и економским потрибама Буњеваца и Шокаца, нису имали за циљ да буду тумачи наших жеља и осићаја, нису настојавали, да међу нама шире националну свист и културу, већ су једино излазили ради тога, да својим господарима врбују гласаче.”

Унутар нашироко познатог сомборског венца у Париској улици на броју 7, налазило се уредништво и администрација и то је била адреса на коју су се могли одазвати писаним путем, или лично, сви они које уредништво јавно позива на сарадњу како би помогли у представљеном науму. Страна са огласима и објавама продаваца, трговаца и занатлија је редовна, а чини се да је у позиву на претплату за лист постојао и одређен попуст на пружане услуге и робу. Цена годишње претплате је била 52 динара, док је поједначни број коштао 1 динар. Из овога можемо претпоставити да је планирано да лист траје дуже. Међутим, јасно је утврђено да је последњи број изашао августа исте 1934. године, када се појављује и први број листа Даница.

Када је реч о садржају, морамо споменути рубрику Разне вистии ca свих стирана која је обиловала кратким информативним новинским чланцима са разним новостима из света. Нећемо заборавити ни то да је уредништво штампало вести које су се тицале ширег подручја, на којем живи буњевачка и шокачка популација, о чему нам говори, као пример, вест о Борби око елекииричне ситрује у Бајмоку или стубац о Раgу сомборске Пољойривреgне берзе у йрошлој іоgини итд. Овај лист кратко је трајао, више од деценије је протекло до наредне појаве једног листа који се обраћао Буњевцима и Шокцима. 


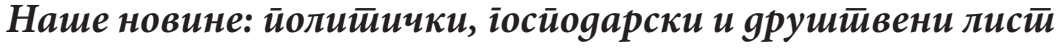

Током окупације Бачке од стране мађарских фашистичких трупа поменути Грго Вуковић урећивао је Наше новине: йолийички, йривреgни и gрушишвени листи, који је излазио у Сомбору од 2. априла 1943. до 6. октобра 1944. године. Издавач и одговорни уредник овог листа био је адвокат и народни заступник у будимпештанском парламенту. Лист је био штампан латиницом, у ротационој штампарији Јосипа Бошњака на истој адреси где се налазило и уредништво, и био је намењен Буњевцима и Шокцима. Имао је тираж од 5.000 примерака. Штампан је на осам страна и садржавао је илустрације.

На страницама је доносио сталне рубрике: Преіле ванске сийуације,

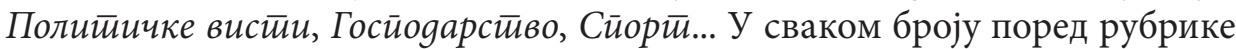
Занимљивостии доносио је прозне и лирске текстове, стално позивајући на сарадњу младе таленте. Од сталних сарадника треба споменути Антуна Карагића, Матију Колара, Ивана Димића, Петра Царева, једног од уредника листа и Ивана Мироницког. Грго Вуковић је у уводнику првог броја између осталог написао:

„Покретајући овај лист, дајемо му наслов Наше новине са искреном жељом, да то буду одиста наше новине са надом и увирењем да ће Haше новине бити новине свију нас и за све нас, који припадамо буњевачком и шокачком пуку...”

Поред пропагандне црте која готово у потпуности обележава Наше новине, као лист подржаван од стране мађарских окупационих власти, овај лист заиста јесте садржавао и бројне друге прилоге, чак и књижевне сегменте, те га овом приликом само и помињемо, без навођења кључних индикација и ипак главних обележја листа који излази у ратно доба и представља надасве још један алат у служби фашистичких савезника у Бачкој. Међутим, поред целокупне посвећености листа актуелностима, ратним дешавањима, политици, преношењу наредби и обавештења окупационих власти, у њему су место нашле и песме, ${ }^{10}$ кратке приче, одломци, разни савети, чак и басне.

10 У броју од 16. 4. 1943. на страни 8 објављена је песма детета, Марије Вујковић-Ломић, Пролићу се веселимо!, за коју уредник испод стихова песме наводи да је салашарско дете из околине Суботице, које је радост пронашло у природи након пресељења породице у град, те је жал за природом потакнула младу Буњевку да спева стихове. 
Рубрике Прича Наших новина, Роман Наших новина, забавне рубрике, бајке за најмлађе или текстови из научних области попут онога о Рентгеновом уређају или новим археолошким открићима у Данској, рецимо, у случају једног чланка, заиста чине разноврсним овај лист и из броја у број, а након прве три или четири обавезне стране, лист као да доживљава трансформацију, прелази у сасвим другу стварност и отвара врата садржајима невезаним за рат, страдања, политику и тешко доба уопште. ${ }^{11}$ уредник се браћа бројним сарадницима који пишу, позива на сарадњу, када год има прилику, пласира поруке, приче из историје, или штампа поучне текстове и савете, често и путем објављивања текстова верске садржине.

Приликом сумирања ипак није могуће отети се утиску да покретач и главни уредник листа др Грго Вуковић ипак чини озбиљну политичку агитацију, а што је евидентно у сваком наредном броју листа, и то такву пропаганду која иде на корист фашистичким окупаторима и њиховим сарадницима. Према свему доступноме, лист је превалентно политички, послушнички, а затим заиста и забавни, едукативни и пропратно књижевни, упркос наводима самог уредника које цитирамо:

„Поздрављајући са овим мислима наше драге читаоце, желимо истаћи, да ће Наше новине за вриме овог свитског рата са овим редцима и завршити политизирање. Данашња вримена нису за политику, нису за политичка расправљања, јер она могу врло лако да створе раздор међу људима, док је наш циљ да Буњевци и Шокци буду сложни, јер само слогом ћемо моћи постићи наше жеље."

\section{Закључак}

Пред сам завршетак приказа буњевачке периодике у Сомбору у периоду од 1882. до 1944. године, уместо закључка, да се подсетимо да је Сомбор друге половине деветнаестог и прве половине двадесетог века плодно тле за богато издаваштво, нарочито периодичних издања, листова и новина на српском, мађарском, немачком и буњевачком језику. Поводом 150 година од објављивања листа Ийар, прве штампане периодике у Сомбору, у Градској библиотеци Карло Бијелицки, 28. децембра 2015. године отворена је изложба 150 іооина сомборске йериоgике на којој су говориле ауторке

Како је немогуће у краћем осврту на свих пет листова представити све оно што се у њима штампало, овде ћемо ипак, за сам крај, издвојити као пример, чланак Десети буюевачких йословища у броју од 7. 5. 1943. са стране 8. 
изложбе Горана Копоран и Наташа Плавшић. Изложба је стална поставка и на паноима пружа кратак опис и изглед бројне периодике, тако карактеристичне за једну високо развијену грађанску средину. Захваљујући пре свега истраживању Радивоја Стоканова, изучавању овог дела фонда у установи, потом залагањем ауторки поменуте изложбе при осмишљавању паноа, понеки случајан посетилац би могао каквом приликом постати заинтересован и узети, прелистати неке од страница заиста пребогате сомборске штампе у којој значајно место, неизоставно и непорециво, припада периодици на буњевачком језику. Тако и овај рад има ту латентну функцију: да привуче пажњу, потакне интересовање за ову тематику; не само да пружи преглед штампе. Актуелизација буњевачке штампе требало би да охрабри заинтересоване да истражују ове прилично заборављене историјске изворе.

Све до сада наведено јесте покушај сажетог систематичног приказа штампе на буњевачком језику која је или излазила у Сомбору или је само одређени период, као што је то случај са листом Невен, Сомбор био место излажења. Напокон, овај рад део је веће целине планиране за објављивање у којој ће читалац моћи да чита изабране аутентичне пасусе новина које су историјско сведочанство активности буњевачког грађанског слоја у циљу очувања свог националног идентитета на територији Града Сомбора, или још шире, на подручју Бачке. Како су права на национално одређење тек релативно недавно поново омогућена Буњевцима, у склопу активности које доприносе ревитализацији свести о њиховој народности, и овај чланак, надамо се, имаће своје место, не само у ретроспективи историје Буњеваца, већ и као неизоставни део историје Града Сомбора. 


\section{Literatura:}

1. Bunjevac: list obće naobrazbe i napridka. Sombor: Ivan Batori, 1882.

2. Danica: nezavisni informativni list. Sombor: Stipan Dujmović, 1934.

3. Stevan Vasiljević. Znameniti Somborci. Novi Sad: Slavija, 1989. (na ćirilici)

4. Miloš Petrović i Vladimir Jerković, Alternativa-Povelja-Statut: normativni akti somborske lokalne samouprave u periodu 1749-1918. Sombor: Gradska biblioteka Karlo Bijelicki u Somboru, 2016. (na ćirilici)

5. Miloš Petrović i Vladimir Jerković. Istorija Sombora - grad kroz vekove. Sombor: Gradska biblioteka „Karlo Bijelicki”, 2018. (na ćirilici)

6. Nataša Plavšić i Gorana Koporan. 150 godina somborske periodike, katalog izložbe Sombor: Gradska biblioteka „Karlo Bijelicki”, 2016. (na ćirilici)

7. Naše novine: politički, gospodarski i društveni list. Sombor: Grgo Vuković, 19431944.

8. Neven: zabavni i poučni misečnik. Sombor: Mijo Mandić, 1884-1887.

9. Vojvodina: politički list Bunjevačko-šokačke stranke. Sombor: Ernest Bošnja, 1927. 


\author{
Vladimir Jerković \\ Sombor \\ vladimirjerkovic@yahoo.com
}

\title{
PERIODICALS PUBLISHED IN THE BUNJEVAC LANGUAGE IN SOMBOR IN THE PERIOD 1882-1944
}

\begin{abstract}
This paper represents an attempt to achieve a systematic and abbreviated review of the periodicals published in the Bunjevac language in Sombor or, as in the case of Neven, this town was the place of publication only for a certain period of time. Namely, this paper represents a version of a historiographical documenting, summarizing all the necessary records within a single article and comprising the segments of the content, as well as indices and portrayals considering the retrospective on the cultural heritage accomplished by the urban activities of Bunjevac population. There are five periodicals described. Finally, this paper contains a specific literature history that provides readers with all the generalities and peculiarities accompanied with direct insight and introduction regarding the selected articles and columns of the papers that build the firm evidence for the authentic activities of Bunjevac citizens aimed to preserve their national identity both in Sombor and Bačka region. Five newspapers were published in Sombor in the period 1882-1944: Bunjevac: list obće naobrazbe i napridka, Neven: zabavni i poučni misečnik, Vojvodina: politički list Bunjevačko-šokačke stranke, Danica: nezavisni informativni list and Naše novine: politički, gospodarski i društveni list.
\end{abstract}

Keywords: periodicals, Bunjevac language, Sombor, Bunjevci, literature, politics.

Примљено: 3. септембра 2018.

Исправке: 17. октобра 2018.

Прихваћено: 1. новембра 2018. 